\title{
Final Report Nucleic Acid System - PCR, Multiplex Assays and Sample Preparation Project
}

R.P. Koopman, R.G. Langlois, S. Nasarabadi, W. J. Benett, J.B. Richards, D.R. Hadley, R.R. Miles, S.B. Brown, P.L. Stratton, F.P. Milanovich

\section{April 30, 2001}

U.S. Department of Energy

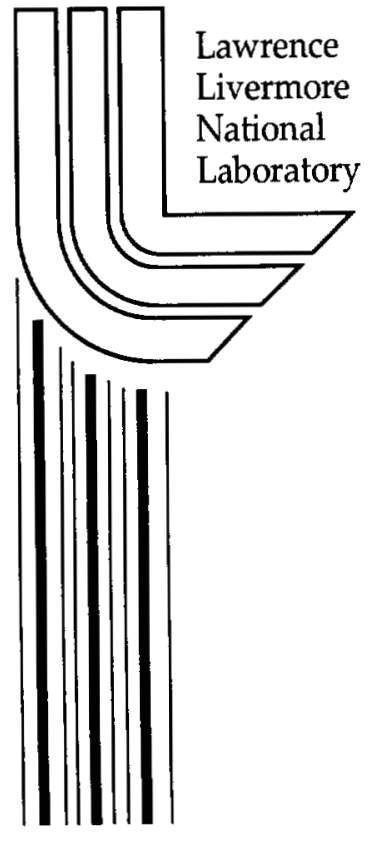




\section{DISCLAIMER}

This document was prepared as an account of work sponsored by an agency of the United States Government. Neither the United States Government nor the University of California nor any of their employees, makes any warranty, express or implied, or assumes any legal liability or responsibility for the accuracy, completeness, or usefulness of any information, apparatus, product, or process disclosed, or represents that its use would not infringe privately owned rights. Reference herein to any specific commercial product, process, or service by trade name, trademark, manufacturer, or otherwise, does not necessarily constitute or imply its endorsement, recommendation, or favoring by the United States Government or the University of California. The views and opinions of authors expressed herein do not necessarily state or reflect those of the United States Government or the University of California, and shall not be used for advertising or product endorsement purposes.

This work was performed under the auspices of the U. S. Department of Energy by the University of California, Lawrence Livermore National Laboratory under Contract No. W-7405-Eng-48.

This report has been reproduced directly from the best available copy.

Available electronically at http://www.doe.gov/bridge

Available for a processing fee to U.S. Department of Energy

and its contractors in paper from

U.S. Department of Energy

Office of Scientific and Technical Information

P.O. Box 62

Oak Ridge, TN 37831-0062

Telephone: (865) 576-8401

Facsimile: (865) 576-5728

E-mail: reports@adonis.osti.gov

Available for the sale to the public from

U.S. Department of Commerce

National Technical Information Service

5285 Port Royal Road

Springfield, VA 22161

Telephone: (800) 553-6847

Facsimile: (703) 605-6900

E-mail: orders@ntis.fedworld.gov

Online ordering: http://www.ntis.gov/ordering.htm

OR

Lawrence Livermore National Laboratory

Technical Information Department's Digital Library

http://www.llnl.gov/tid/Library.html 


\title{
Final Report \\ Nucleic Acid System - PCR, Multiplex Assays and Sample Preparation Project
}

\author{
Ronald P. Koopman, Richard G. Langlois, Shanavaz Nasarabadi, \\ William J. Benett, James B. Richards, Dean R. Hadley, Robin R .Miles, \\ Steve B. Brown, Paul L. Stratton, Fred P. Milanovich
}

April 20, 2001

\section{Project Objective}

The objective of this project was to reduce to practice the detection and identification of biological warfare pathogens by the nucleic acid recognition technique of PCR (polymerase chain reaction). This entailed not only building operationally functional instrumentation but also developing the chemical assays for detection of priority pathogens. This project had two principal deliverables: (1) design, construct, test and deliver a 24 chamber, multiplex capable suitcase sized PCR instrument, and (2) develop and reduce to practice a multiplex assay for the detection of PCR product by flow cytometry. In addition, significant resources were allocated to test and evaluation of the Hand-held Advanced Nucleic Acid Analyzer (HANAA).

This project helps provide the signature and intelligence gathering community the ability to perform, on-site or remote, rapid analysis of environmental or like samples for the presence of a suite of biological warfare pathogens.

\section{Project Context}

This project is part of a more comprehensive effort to build an automated, portable biological detection instrumentation capability. Other critical areas of development, not covered by this current project, are: sample preparation (nucleic acid extraction and purification), and integration of the instrument components into other instrument systems under development by other organizations. We anticipate that all of the critical components will come together into a comprehensive system through additional projects being initiated, and through close collaborative efforts among the participating organizations.

\section{Background}

This project is a follow-on to eight years of technology development that began with LLNL internal funding under which the micro-fabricated PCR thermal chamber was conceived and developed. This was followed by a three year DARPA funded project (1993-96) that resulted in a suitcase-sized miniature PCR instrument that was successfully demonstrated at JFT III in Sep 1996. In 1998 CMO funded design and construction of a field hardened 10 chamber PCR 
instrument with 2-plex capability (ANAA) which was delivered to NMRI. In 1999 CMO funded design and construction of a four chamber, handheld instrument (HANAA), a suitcase sized 24 chamber instrument, and initial work on multiplex PCR flow analysis using the Luminex 100 and multiplex assay reagents.

The project took advantage of lessons learned in field testing as well as high leverage improvements made during the year to articulate the next generation of thermal cycling instruments. These improvements include individual chamber thermal control on multiple chamber PCR instruments, miniature optics and improved thermal design to facilitate faster cycling, less power consumption and, potentially, flow though fluidics for incorporation of automatic sample introduction as it becomes available.

This project continued to draw upon the resources and personnel (scientists, engineers and technicians) from the previous work in this area. The facilities to perform the tasks described herein include static and dynamic testing chambers, a state of the art microfabrication facility, complete electronic design, layout and fab facility, mechanical fab including plastic extrusions, design modeling, system engineering, PCR and nucleic acid sequencing expertise, packaging and extensive field test experience.

\section{Tasks}

Task 1. Design, build, test, and deliver to NMRI a man-portable 24 - chamber PCR instrument with dual assay per chamber, independent temperature control, dual plenum, internal temperature calibration, bi-axial redundant power and control circuitry, and internal/external computer controls. Size must not exceed commercial airline carry-on limit.

Task 2. Design, build and test a low power, light weight, portable PCR sample preparation module for the hand-held PCR device.

Task 3. Perform acceptance testing on an auto sample preparation device developed with AR\& DC funds. Design and breadboard an interface to the above instrument, a cycle chamber capable of autonomous sample introduction and retrieval.

Task 4. Select control software and develop code to permit random time access to an arbitrary set of parallel operating thermal cycle chambers.

Task 5. Transition the LLNL-developed virtual impactor bioaerosol collector technology to potential commercial vendors.

Task 6. Develop and evaluate multiplex analysis assay reagents and protocols for the simultaneous detection of PCR products from B. globigii and E. herbiocola and related species. 
Task 7. Evaluate IR fluorescent reporter dyes; test the Luminex 100 instrument using the reagents and protocols from task 6 , and demonstrate this technology at an appropriate laboratory or field trial.

\section{Results}

Task 1. A man-portable 24-chamber PCR instrument, the PolyHANAA, was designed, built, tested and delivered to Armed Forces Institute of Pathology (AFIP). This instrument features dual assay per chamber, independent temperature control, dual plenum, internal temperature calibration, bi-axial redundant power and control circuitry, and internal/external computer controls. This instrument is described in detail in attachment 7.

Task 2. A brief report on the Hand-held Field-portable PCR Sample Preparation Device is included as attachment 4. This task demonstrated the feasibility of assembling a plastic pouch for field-usable sample preparation. It was demonstrated that the pouch could contain pre-stored reagents. It was demonstrated that the cam device could provide metering, valving and pumping functions. Further work is needed to test and design for long-term reagent storage in the pouch and to design PCR chambers specifically for the pouch. Further work could also be directed at designing pouches that could be used manually without need of any external device to provide metering or mixing functions.

Task 3. The Miniature Sample Preparation Instrument developed with AR\&DC funds is described in reference 9. Performance testing of the instrument by Cepheid is also described in that report. Additional performance testing was conducted at LLNL. The result was that this initial design, where the entire module was assembled after each run, never did work well. The problem was with assembly of the module. It would leak due to poor sealing of the gaskets or the hydrophobic filters leaking. It was not possible to get this design to perform well, hence the change in design to the current cartridge based system.

A flow-through PCR thermocycler instrument, using MATCI (Miniature Analytical Thermal Cycler Instrument) hardware was designed and built, with the ability to accept samples from the automated sample preparation device. This instrument is capable of automated sample handling, including thermal cycling, and is described in attachment 8.

Task 4. Control software was selected and computer code developed to provide a capable user interface and to control and permit random time access to parallel operating thermal cycle chambers on the 24-chamber instrument. This work is described in attachment 7.

Task 5. Work was performed in collaboration with RI to incorporate our virtual imactor as a front end to their SASS 2000 unit, thereby increasing the aerosol collection rate by a factor of ten. Performance of the hybrid collector was extensively characterized. A technology transfer plan was developed and implemented. The major components were (1) a drawing package, (2) modification of the prototype consistent with the drawing package and 
(3) disclosure of the technology availability consistent with US government fairness of opportunity regulations. For the latter, a technology transfer agent was identified. Additions were made to the virtual impactor input by designing a particle fractionator and designs to improve air flow between the impactor and the cyclone collector were evaluated. The results are summarized in RI-LLNL Hybrid Biological Aerosol Collector, which is included as attachment 2. A drawing package was delivered. RI obtained an SBIR grant to complete development and commercialization of the combined unit, completing all work on this task.

Task 6. Multiplex analysis assay reagents and protocols for the simultaneous detection of PCR products from B. globigii , E. herbiocola and related species were developed and tested. This work is described in attachment 3.

Task 7. Multiplex PCR amplicons were tested on the Luminex 100 instrument using the reagents and protocols from task 6 . Demonstration of this technology was done in the laboratory following the test plan included as attachment 6 . The results are described in attachment 3.

LLNL recently completed the construction of a hand-held 4-chamber PCR instrument with real-time Taqman detection capability. This hand-held advanced nucleic acid analyzer (HANAA) can perform complete PCR runs in 20 minutes, with automated calling of positive samples. The Integrated Community Exercise Demonstration (IC Demo) provided an opportunity to evaluate the HANAA in on site analysis of field samples. A test plan for the field evaluation of HANAA was written and is included as attachment 5. LLNL participated in two parts of the IC Demo. At the LLNL Main Campus Test (9/20-24/99), selected samples were analyzed with the HANAA, and an ABI 7700 PCR instrument was used to provide standard laboratory analyses of test samples. At the DOE/NTS Test (10/12-13/99), selected samples were analyzed with the HANAA. An additional laboratory evaluation of HANAA was performed at LLNL subsequent to the IC Demo tests (12/7-15/99). The results are summarized in Report on the Results of Field Tests with the LLNL Hand-held Realtime PCR Instrument (HANAA) at the IC Demo,. The report summarizes methods used for these studies, PCR assay characterization, 7700 results from the IC Demo, HANAA results from the IC DEMO, and the results of the laboratory evaluation of HANAA, and is included as Attachment 1. The conclusions are:

- The LLNL 4-chamber HANAA was successfully used for on site real-time PCR detection of bacterial spores in two field trials performed at LLNL and NTS.

- A laboratory evaluation of HANAA showed good performance in detecting 3 different bacterial targets down to concentrations of $10^{\wedge} 3 \mathrm{cfu} / \mathrm{ml}$.

- Further effort may be required to reduce instrument down-time, and to fully evaluate its performance in different temperatures and light levels that may be encountered in field use.

\section{Deliverables}

a. Schematics for man-portable 24-chamber device and portable PCR sample prep module. (Tasks 1 \& 2)

A drawing package for the 24-chamber instrument was delivered to $\mathrm{CMO}$ on $12 / 31 / 99$. A brief report describing the portable PCR sample prep module, 
including exploded component views, and module function is included as attachment 4 . Drawings for the portable PCR sample prep module are being delivered with this report.

b. Man-portable 24-chamber PCR instrument and PCR sample preparation module. (Tasks $1 \& 2$ )

The 24-chamber instrument (PolyHANAA) was delivered to Ted Hadfield, AFIP, on 2 April 2001. A report describing it is included as attachment 7. The portable PCR sample prep module was tested in the laboratory for function and is written up in attachment 4 . Since more work is needed on the device, it has been retained by LLNL pending the decision to do more work on it.

c. Test plan and test results on Luminex 100 instrument. (Task 7)

This test plan is included as attachment 6 . The results are documented in the report, previously delivered and included as attachment 3 .

d. Test plan and test results on laboratory or field trial. (Task 7) This test plan is included as attachment 5 . The results are documented in the report, previously delivered and included as attachment 1.

e. $\quad$ Final technical report. (Task 1-7)

This document is the final technical report and the final deliverable on this project.

\section{Attachments and/or References}

1. Langlois R, Nasarabadi S, Report on the Results of Field Tests with the LLNL Hand-held Real-time PCR Instrument (HANAA) at the IC Demo," UCRL-ID137057, December 1999.

2. Bergman W, Shinn J, Lochner R. Sawyer S. RI_LLNL Hybrid Biological Aerosol Collector, UCRL-ID-135282, July 1999.

3. Venkateswaran K, Nasarabadi S, Langlois R, Laboratory Tests of Multiplex Detection of PCR Amplicons Using the Luminex 100 Flow Analyzer, UCRL-ID139001, May 5, 2000.

4. Miles R, Schumann D, Meyer P, Frattaroli R, Trevino J, Hand-held Fieldportable PCR Sample Preparation Device, UCRL-ID xxxxxx, May 2000.

5. Langlois R, Test Plan for the Field Evaluation of the LLNL Handheld Real-time PCR Instrument (HANAA), August 4, 1999

6. Langlois R, Test Plan for Multiplex PCR Product Identification with the Luminex LX-100 Flow Cytometer, August 27, 1999

7. Richards J, B., Stratton P. L., Benett W. J., Koopman R.P., Milanovich F. P., "Final Report for the PolyHANAA," UCRL-Idxxxxxxx, April 2001. 
8. Global FIA, FlowThru PCR, Revision 1.2, July 22, 1999

9. Belgrader P, A Minature Sample Preparation Instrument (Phase1), FY99 Final Report, UCRL-ID-134506, May 1999, not included as an attachment. 